\title{
Impact of Robinia pseudoacacia stand conversion on soil properties and bacterial community composition in Mount Tai, China
}

\author{
Kun $\mathrm{Li}^{1 \dagger}$, Xu Han ${ }^{1 \dagger}$, Ruiqiang $\mathrm{Ni}^{1}$, Ge Shi ${ }^{1}$, Sergio de-Miguel ${ }^{2,3}$, Chuanrong Li ${ }^{1 *} \mathbb{D}$, Weixing Shen ${ }^{4}$, Yikun Zhang ${ }^{4}$ and \\ Xingzhong Zhang ${ }^{4}$
}

\begin{abstract}
Background: Robinia pseudoacacia is a widely planted pioneer tree species in reforestations on barren mountains in northern China. Because of its nitrogen-fixing ability, it can play a positive role in soil and forest restoration. After clearcutting of planted stands, R. pseudoacacia stands become coppice plantations. The impacts of shifting from seedling to coppice stands on soil bacterial community and soil properties have not been well described. This study aims to quantify how soil properties and bacterial community composition vary between planted seedling versus coppice stands.
\end{abstract}

Methods: Nine $20 \mathrm{~m} \times 20 \mathrm{~m}$ plots were randomly selected in seedling and coppice stands. The bulk soil and rhizosphere soil were sampled in summer 2017. Bulk soil was sampled at $10 \mathrm{~cm}$ from the soil surface using a soil auger. Rhizosphere soil samples were collected using a brush. The soil samples were transported to the laboratory for chemical analysis, and bacterial community composition and diversity was obtained through DNA extraction, 16S rRNA gene amplification and high-throughput sequencing.

Results: The results showed that, compared to seedling plantations, soil quality decreased significantly in coppice stands, but without affecting soil exchangeable $\mathrm{Mg}^{2+}$ and $\mathrm{K}^{+}$. Total carbon $(\mathrm{C})$ and nitrogen $(\mathrm{N})$ were lower in the rhizosphere than in bulk soil, whereas nutrient availability showed an opposite trend. The conversion from seedling to coppice plantations was also related to significant differences in soil bacterial community structure and to the reduction of soil bacterial a-diversity. Principal component analysis (PCA) showed that bacterial community composition was similar in both bulk and rhizosphere soils in second-generation coppice plantations. Specially, the conversion from seedling to coppice stands increased the relative abundance of Proteobacteria and Rhizobium, but reduced that of Actinobacteria, which may result in a decline of soil nutrient availability. Mantel tests revealed that $\mathrm{C}$, N, soil organic matter (SOM), nitrate nitrogen $\left(\mathrm{NO}_{3}{ }^{-} \mathrm{N}\right)$ and available phosphorus positively correlated with bacterial community composition, while a variation partition analysis (VPA) showed that $\mathrm{NO}_{3}{ }^{-}-\mathrm{N}$ explained a relatively greater proportion of bacterial distribution (15.12\%), compared with C and SOM. Surprisingly, N showed no relationship with bacterial community composition, which may be related to nitrogen transportation.

(Continued on next page)

\footnotetext{
* Correspondence: chrlisd@126.com; chrli@sdau.edu.cn

${ }^{\dagger} \mathrm{Kun} \mathrm{Li}$ and Xu Han contributed equally to this work.

${ }^{1}$ Mountain Tai Forest Ecosystem Research Station of State Forestry Administration / Key Laboratory of State Forestry Administration for Silviculture of the Lower Yellow River, Tai'an 271018, Shandong, China Full list of author information is available at the end of the article
}

\section{Springer Open}

(c) The Author(s). 2021 Open Access This article is licensed under a Creative Commons Attribution 4.0 International License, which permits use, sharing, adaptation, distribution and reproduction in any medium or format, as long as you give appropriate credit to the original author(s) and the source, provide a link to the Creative Commons licence, and indicate if changes were made. The images or other third party material in this article are included in the article's Creative Commons licence, unless indicated otherwise in a credit line to the material. If material is not included in the article's Creative Commons licence and your intended use is not permitted by statutory regulation or exceeds the permitted use, you will need to obtain permission directly from the copyright holder. To view a copy of this licence, visit http://creativecommons.org/licenses/by/4.0/. 
(Continued from previous page)

Conclusions: The conversion from seedling to coppice stands reduced soil quality and led to spatial-temporal homogenization of the soil bacterial community structure in both the rhizosphere and bulk soils. Such imbalance in microbial structure can accelerate the decline of $R$. pseudoacacia. This may affect the role of $R$. pseudoacacia coppice stands in soil and forest restoration of barren lands in mountain areas.

Keywords: Black locust coppice plantation, Forest restoration, Afforestation, Microbial structure, Soil nutrient, Soil quality

\section{Background}

Robinia pseudoacacia (Black locust) is a leguminous tree which can rapidly fix nitrogen $(\mathrm{N})$ from the atmosphere via Rhizobium (Zhang et al. 2019) and further alter soil properties by increasing mineral $\mathrm{N}$ (Medina-Villar et al. 2016). $R$. pseudoacacia is able to disperse quickly and colonize a broad range of xeric habitats, including steep rocks or toxic man-made substrata (Cierjacks et al. 2013), and has been extensively naturalized in the temperate regions of North America, Europe, and Asia (Sabo 2000; Lee et al. 2004; Vítková et al. 2017; Yang et al. 2019). Natural reproduction of $R$. pseudoacacia plantations is primarily vegetative through root suckering and stump sprouting, allowing vigorous regeneration after coppicing and disturbance (Peng et al. 2003). However, after two or three rotations, the productivity of $R$. pseudoacacia coppice plantations tends to decline (Cierjacks et al. 2013), which may further jeopardize its ecological role in soil and forest restoration.

Plant community structure and productivity in natural environments depend, among other factors, on soil nutrient availability and soil microbial communities (Reynolds and Haubensak 2009; Vitkova et al. 2015; Liu et al., 2018a; Chen et al. 2020). Soil nutrient availability can alter soil processes catalyzed by soil microbial communities (Yang et al. 2016). Therefore, changes in soil microbial community composition can affect the plant community (Balota et al. 2013; Ma et al. 2018) and nutrient absorption by plants (Weidner et al. 2015; Zhang et al. 2018b). In turn, plants can directly and indirectly influence soil microbial communities by the effect of root exudation and litters (Sasse et al. 2018). So plant-soil feedback may play a key role in plant species coexistence and phylogeny of plant community (Crawford et al. 2019).

Rhizosphere is a critical interface supporting the exchange of resources between plants and the surrounding soil environment, which provides microhabitats and niches for diverse microorganisms and microbial species (Philippot et al. 2013; Mendes et al. 2013). Rhizosphere microorganisms play a key role in plant growth and soil properties, especially in the rhizosphere niche (Philippot et al. 2013; Zhang et al. 2018a), which influences several plant physiological processes such as growth and energy metabolism affecting overall plant health (Fonseca et al. 2018). Generally, there are significant differences between rhizosphere and bulk soil microenvironments, the most obvious of which is that the higher nutrient content and root exudates in the rhizosphere contribute to improving soil carbon and nitrogen concentrations (Yin et al. 2018). Such differences may affect the composition of the rhizosphere microbial community (Neumann et al. 2014). Soil properties and their ecological processes provide a scientific basis for understanding the interaction between root physiological activity and soil physical and biological environments. At the same time, rhizosphere dynamics may be a key driver for understanding tree growth mechanisms.

Previous research has reported the high capacity of $R$. pseudoacacia for nitrogen fixation (Buzhdygan et al. 2016), and higher $\mathrm{N}$ mineralization and nitrification rates in $R$. pseudoacacia plantations compared to surrounding soils (Williard et al. 2005). Moreover, the excess of $\mathrm{N}$ can accumulate in the soil (Berthold et al. 2009) by means of root exudates, contributing to increasing soil fertility (Joëlle et al. 2010). The main nitrogen form uptaken by plants is inorganic nitrogen including nitrate and ammonium. $R$. pseudoacacia benefits from nitrogen fixation associated with symbiotic rhizobia in root nodules (Cierjacks et al. 2013). The reduction of soil $\mathrm{N}$ availability induces nodulation and biological nitrogen fixing of $R$. pseudoacacia in order to sustain the required nitrogen amounts for plant growth (Mantovani et al. 2015). Therefore, both bacteria and $\mathrm{N}$ play an important role in the growth and development of $R$. pseudoacacia plantations.

With the development of $R$. pseudoacacia coppice plantations through stand conversion, unexpected problems have arisen in Mount Tai (China) forest ecosystems, including the decline of landscape quality, soil erosion and plant dwarfing, in line with previous research suggesting tree growth decline and trunk shape worsening (Geng et al. 2013). However, to date, most studies have attempted to investigate the effects of conversion from natural forests to plantations on soil properties, soil microbes and their community structure (Zhang et al. 2017; Yang et al. 2018). In consequence, there is a gap in knowledge concerning the effects of the conversion from seedling plantations to coppice stands. 
Radtke et al. (2013) showed that repeated clear-cuttings every 20-30 years favored the spread of $R$. pseudoacacia. Yet, the effects of shifting from seedling to coppice plantations on soil properties and soil microbes are not yet well understood, and information is scarce. We hypothesized that (1) the changes caused by the conversion of seedling to coppice stands lead to decline of soil quality, and to alterations in soil bacterial community composition, (2) nutrient availability plays an important role in shaping the bacterial community, and (3) the relative abundance of Rhizobium decreases in coppice plantations. The aims of this study were to (1) shed light on the effects of shifting from seedling to coppice stands in R. pseudoacacia plantations on soil properties and soil bacterial community composition, especially on Rhizobium, and (2) investigate the relationships between soil properties and bacterial community composition in seedling and coppice plantations, respectively.

\section{Materials and Methods Study area}

This study was conducted in Mount Tai region of Shandong Province, eastern China. The region is characterized by a typical temperate climate. The mean annual temperature is $12.8^{\circ} \mathrm{C}$, and the mean annual precipitation is $1124.6 \mathrm{~mm}$. In the $1920 \mathrm{~s}, R$. pseudoacacia was introduced to Mount Tai because of its potential for soil and forest restoration. Afforestation was mainly conducted between 1956 and 1958 through seedling planting. However, with increasing timber demand for use in construction, seedling plantations were gradually harvested leading to naturally-regenerated coppice stands. As a result, nowadays, most $R$. pseudoacacia stands are coppice plantations, mainly distributed along an altitudinal gradient from 500 to $1000 \mathrm{~m}$ above sea level, and southern aspects.

The study was performed in: i) a first-generation seedling plantation stand (hereinafter referred to as "First", “F”, $36^{\circ} 16^{\prime} 45^{\prime \prime} \mathrm{N}, 117^{\circ} 3^{\prime} 26^{\prime \prime} \mathrm{E}$ ), ii) a first-regeneration coppice stand generated after clear-cutting of a seedling stand (hereinafter referred to as "Second", "S", 36 16'40" 'N,117 $03^{\prime} 21^{\prime \prime} \mathrm{E}$ ) and iii) a second-generation coppice stand generated after clear-cutting of a first-generation coppice stand (hereinafter referred to as "Third", "T", $36^{\circ} 16^{\prime} 40^{\prime \prime} \mathrm{N}, 117^{\circ} 3^{\prime} 22^{\prime \prime} \mathrm{E}$ ) (Fig. S1). The understory vegetation is mainly composed of Vitex negundo, Oplismenus undulatifolius, Digitaria sanguinali, Paspalum thunbergii, Rubia cordifolia and Oxalis corniculate. The three forest stands were close to each other as shown in Fig. S1, and therefore represented homogeneous conditions in terms of topography (i.e., slope $25^{\circ}$ and southwestern aspect), previous land use (i.e., stands developed from barren land) and initial soil characteristics and taxonomy (i.e., classified as Alfisols). Soil moisture was about $10 \%$. The microbial biomass of carbon in the three stand development stages were 247, 200 and 190 $\mathrm{mg} \cdot \mathrm{kg}^{-1}$, respectively, and those of nitrogen were 41, 28 and $25 \mathrm{mg} \cdot \mathrm{kg}^{-1}$, respectively (unpublished data).

\section{Sampling}

Three $20 \mathrm{~m} \times 20 \mathrm{~m}$ plots were randomly selected in each seedling and coppice stand (i.e., a total of nine plots). The bulk soil and rhizosphere soil were sampled in the nine above-mentioned sample plots in August 2017. Bulk soil was sampled at $10 \mathrm{~cm}$ from the soil surface by using a soil auger (length $50 \mathrm{~cm}$, diameter $5 \mathrm{~cm}$, volume $100 \mathrm{~cm}^{3}$ ). Rhizosphere soil samples were collected by brush ( 5 samples per plot). The soil samples were transported on ice to the laboratory, where they were sieved (mesh size $2 \mathrm{~mm}$ ) and divided into two parts, one was air-dried and stored at room temperature prior to chemical analysis and the other was stored at $-80^{\circ} \mathrm{C}$ for further analysis. Hereafter in this manuscript, FR, SR and TR refer to the rhizosphere of $\mathrm{F}, \mathrm{S}$ and $\mathrm{T}$, respectively; and FNR, SNR and TNR refer to bulk soil of F, S and T, respectively.

\section{Analysis of soil physicochemical properties}

Total soil carbon $(\mathrm{C})$ and nitrogen $(\mathrm{N})$ contents were measured by dry combustion in an Elemental Analyzer (Costech ECS4010, Italy). The soil nitrate $\left(\mathrm{NO}_{3}{ }^{-} \mathrm{N}\right)$ and ammonium $\left(\mathrm{NH}_{4}{ }^{+}-\mathrm{N}\right)$ were extracted by shaking $20 \mathrm{~g}$ of fresh soil in $100 \mathrm{~mL}$ of $2 \mathrm{~mol} \cdot \mathrm{L}^{-1} \mathrm{KCl}$ solution for $1 \mathrm{~h}$ and were analyzed with continuous flow analytical system (AA3, German), available N (A.N) was a sum of $\mathrm{NO}_{3}{ }^{-}-\mathrm{N}$ and $\mathrm{NH}_{4}{ }^{+}-\mathrm{N}$, available $\mathrm{P}$ in the soil was measured using the colorimetric method with $0.5 \mathrm{~mol} \cdot \mathrm{L}^{-1}$ $\mathrm{NaHCO}_{3}$ extraction, the total soil phosphorus (P) and available P (A.P) were measured with a continuous flow analytical system (AA3, German), and the soil organic matter (SOM) was measured via the standard Mebius method (Nelson and Sommers 1982). The exchangeable cations $\left(\mathrm{Ca}^{2+}, \mathrm{Mg}^{2+}\right.$ and $\left.\mathrm{K}^{+}\right)$were measured using titration and atomic absorption spectroscopy (AAS, TAS990MFG, China). Soil moisture was determined using the soil core method, and obtained by calculating the ratio of soil mass to total volume $\left(\mathrm{g} \cdot \mathrm{cm}^{-3}\right)$ after ovendrying to a constant weight at $105^{\circ} \mathrm{C}$ (Zhang et al. 2019). To better describe changes in soil properties, soil quality index (SQI) (Guo et al., 2019) was calculated.

$$
S Q I=\sum_{i=1}^{n} W_{i} Y_{i}
$$

where $W$ is the weighting factor for the indicator selected and $Y$ is the score. The final $S Q I$ can be used to evaluate soil quality following vegetation restoration, with a high SQI value indicating a high-quality soil. 
DNA extraction, 16S rRNA gene amplification, and high throughput sequencing

Total genomic DNA from soil samples $(0.5 \mathrm{~g})$ was extracted using CTAB method. Bacterial 16S rRNA genes of distinct regions (V4-V5) were amplified with the primer pair 515F (5'-GTGCCAGCMGCCGCGGTAA-3') and 907R (5'-CCGTCAATTCMTTTRAGTTT-3') with single multiplex identifier (MID) and adaptors (Jiao et al. 2018). The initial enzyme activation was performed at $95^{\circ} \mathrm{C}$ for $5 \mathrm{~min}$, and then 35 cycles of the following program were used for amplification: $95^{\circ} \mathrm{C}$ for $30 \mathrm{~s}, 58^{\circ} \mathrm{C}$ for $30 \mathrm{~s}$ and $72{ }^{\circ} \mathrm{C}$ for $30 \mathrm{~s}$ (Chen et al. 2017). All PCR reactions were carried out with Phusion ${ }^{\circ}$ High-Fidelity PCR Master Mix (New England Biolabs). The 16S rRNA genes were analyzed to evaluate bacterial diversity using IlluminaHiSeq (Novogene Bioinformatics Technology Co., Ltd., Beijing, China).

Sequences were analyzed using QIIME software package (Quantitative Insights Into Microbial Ecology) (Caporaso et al., 2010), and in-house Perl scripts were used to analyse alpha- (within samples) diversities. The low-quality sequences were filtered out using the following criteria: sequences with a length of $<150 \mathrm{bp}$, average Phred scores of $<20$, containing ambiguous bases, and containing mononucleotide repeats of $>8 \mathrm{bp}$ (Ji et al. 2019). Following chimera detection, the remaining highquality sequences were clustered into operational taxonomic units (OTUs) at 97\% sequence identity using UCLUST. A representative sequence was selected from each OTU using default parameters. We picked a representative sequence for each OTU and used the RDP classifier to annotate taxonomic information for each representative sequence (Wang et al. 2007).

\section{Statistical analysis}

Duncan's one-way ANOVA was conducted to examine differences in soil characteristics, $S Q I$ and relative abundance of Rhizobium between bulk and rhizosphere soils. A T-test was conducted to examine differences in Shannon and Simpson indices between bulk and rhizosphere soils. These analyses were performed using SPSS 24.0 (IBM, USA). Principal component analysis (PCA) was conducted to test for differences in the OUT-based community composition using Bray-Curtis distance. The relationships between soil properties and dominant bacterial community composition (TOP 10) were determined using Spearman correlation analysis. Mantel-tests and variation partition analysis (VPA) were used to determine the relative importance of the measured soil properties in shaping soil bacterial community, which were calculated using the Bray-Curtis distance. These analyses were carried out using the "vegan" package of R software (Version 2.15.3). The graphics were drawn using Origin 2019.

\section{Results}

Impact of the conversion to coppice stands on soil quality Soil nutrient contents diminished mostly from seedling to coppice plantations (Table 1). Soil characteristics varied considerably in both rhizosphere and bulk soil from F stands to $\mathrm{T}$ stands. Total $\mathrm{C}, \mathrm{N}$ and $\mathrm{NO}_{3}{ }^{-}-\mathrm{N}$ concentration and SOM content in both the rhizosphere and bulk soil was significantly higher in seedling stands compared to first- and second-generation coppice stands. There were significant differences in $\mathrm{P}$ concentration in the rhizosphere and bulk soil. There was no statistically significant difference in available phosphorous (A.P) concentrations between FNR and SNR, but A. P concentration was significantly greater in FNR and SNR compared to TNR. No differences were found regarding exchangeable ions in bulk soil between seedling and coppice plantation, while significantly higher concentrations appeared in the rhizosphere of coppice plantations compared to seedling stands. The SQI of both bulk soil and rhizosphere was higher in seedling plantations than in coppice stands, i.e., the highest $S Q I$ value (29.14) was found in the rhizosphere of seedling stands whereas the lowest SQI (24.33) was found in the bulk soil of secondgeneration coppice stands.

\section{Differences in soil bacterial abundance and diversity}

In total, 2,562,381 sequences and 2,358,270 combined sequences were obtained. The read lengths ranged from 211 to 407 base pairs (bp), with an average of $373 \mathrm{bp}$. When grouped at the $97 \%$ similarity level, there were 42 different phylotypes in all soils. The dominant groups (TOP 10) across all soil samples (Fig. 1a) were Proteobacteria (30.54\%), Actinobacteria (25.30\%), Acidobacteria (13.94\%), Firmicutes (7.19\%), Verrucomicrobia (6.86\%), Planctomycetes (5.22\%), Chloroflexi (3.87\%), Gemmatimonadetes (2.37\%), Bacteroidetes (1.14\%), and Cyanobacteria $(0.40 \%)$, and these groups accounted for more than $96.43 \%$ of the bacterial sequences. Moreover, the Shannon and Simpson indices for alpha bacterial diversity declined from seedling to coppice plantations and from first-rotation to second-rotation coppice plantations by $2 \%$ and $0.2 \%$, respectively (Table 2 ).

At the genus level (Fig. 1b), the six most abundant bacteria $(\geq 1 \%)$ were Bacillus (4.22\%), Bradyrhizobium (2.82\%), Acidothermus (1.88\%), Bryobacter (1.44\%), Burkholderia-Paraburkholderia (2.00\%) and Streptomyces (1.41\%). The relative abundances of Bacillus and Burkholderia-Paraburkholderia in the rhizosphere were lower than that of bulk soil in seedling plantations, but the opposite trend was found in coppice plantations. In addition, the relative abundance of other bacteria in the rhizosphere was higher than that of bulk soil in seedling and coppice plantations. 
Table 1 Bulk soil and rhizosphere soil properties (mean \pm standard error) of the three types of Robinia pseudoacacia stands following forest conversion from seedling to coppice stands

\begin{tabular}{|c|c|c|c|c|c|c|}
\hline & Rhizosphere & & & Bulk soil & & \\
\hline & $\overline{F R}$ & SR & TR & $\overline{\text { FNR }}$ & SNR & TNR \\
\hline$\overline{N(\%)}$ & $0.38 \pm 0.03 a$ & $0.32 \pm 0.01 b$ & $0.33 \pm 0.01 b$ & $0.43 \pm 0.02 a$ & $0.32 \pm 0.01 \mathrm{c}$ & $0.36 \pm 0.02 b$ \\
\hline C (\%) & $3.80 \pm 0.27 a$ & $3.31 \pm 0.14 b$ & $3.50 \pm 0.15 b$ & $4.56 \pm 0.16 a$ & $3.33 \pm 0.16 c$ & $3.77 \pm 0.30 b$ \\
\hline $\mathrm{P}(\%)$ & $1.58 \pm 0.13 b$ & $1.88 \pm 0.05 a$ & $1.63 \pm 0.08 b$ & $1.66 \pm 0.05 a$ & $0.93 \pm 0.03 b$ & $0.85 \pm 0.02 c$ \\
\hline $\mathrm{C} / \mathrm{N}$ & $10.14 \pm 0.18 b$ & $10.22 \pm 0.31 b$ & $10.57 \pm 0.22 a$ & $10.52 \pm 0.26 a$ & $10.35 \pm 0.47 a$ & $10.51 \pm 0.17 a$ \\
\hline$C / P$ & $2.31 \pm 0.30 \mathrm{a}$ & $1.76 \pm 0.11 \mathrm{c}$ & $2.15 \pm 0.18 b$ & $2.75 \pm 0.10 c$ & $3.59 \pm 0.24 b$ & $4.43 \pm 0.28 a$ \\
\hline N/P & $0.24 \pm 0.03 a$ & $0.17 \pm 0.01 c$ & $0.20 \pm 0.01 b$ & $0.26 \pm 0.01 c$ & $0.35 \pm 0.03 b$ & $0.42 \pm 0.02 \mathrm{a}$ \\
\hline $\mathrm{NO}_{3}{ }^{-}-\mathrm{N}\left(\mathrm{mg} \cdot \mathrm{kg}^{-1}\right)$ & $69.06 \pm 1.53 a$ & $63.29 \pm 1.63 b$ & $59.50 \pm 1.84 c$ & $67.20 \pm 2.99 a$ & $60.52 \pm 1.39 b$ & $60.71 \pm 2.14 b$ \\
\hline $\mathrm{NH}_{4}{ }^{+}-\mathrm{N}\left(\mathrm{mg} \cdot \mathrm{kg}^{-1}\right)$ & $58.60 \pm 1.24 a$ & $58.81 \pm 1.62 \mathrm{a}$ & $55.20 \pm 2.42 b$ & $45.99 \pm 4.02 b$ & $54.25 \pm 0.43 a$ & $39.41 \pm 1.48 c$ \\
\hline A.N $\left(\mathrm{mg} \cdot \mathrm{kg}^{-1}\right)$ & $127.66 \pm 2.27 a$ & $122.10 \pm 2.95 a$ & $114.70 \pm 4.10 \mathrm{~b}$ & $113.19 \pm 4.19 a$ & $114.77 \pm 1.36 b$ & $100.12 \pm 2.87 \mathrm{c}$ \\
\hline A.P $\left(\mathrm{mg} \cdot \mathrm{kg}^{-1}\right)$ & $16.93 \pm 1.26 a$ & $11.18 \pm 0.9 b$ & $8.35 \pm 0.98 c$ & $14.41 \pm 0.91 a$ & $14.24 \pm 1.08 \mathrm{a}$ & $9.60 \pm 1.27 b$ \\
\hline $\operatorname{SOM}\left(g \cdot \mathrm{kg}^{-1}\right)$ & $64.91 \pm 0.92 a$ & $62.84 \pm 1.29 b$ & $50.73 \pm 1.05 c$ & $61.93 \pm 1.78 a$ & $51.69 \pm 0.58 b$ & $46.70 \pm 1.47 c$ \\
\hline Exchangeable $\mathrm{Ca}\left(\mathrm{cmol}^{\mathrm{kg}}{ }^{-1}\right)$ & $48.74 \pm 9.48 b$ & $44.63 \pm 11.21 b$ & $65.83 \pm 12.46 a$ & $61.78 \pm 13.15 a$ & $51.01 \pm 7.96 a$ & $65.26 \pm 11.27 a$ \\
\hline Exchangeable $\mathrm{Mg}\left(\mathrm{cmol} \cdot \mathrm{kg}^{-1}\right)$ & $12.09 \pm 1.60 \mathrm{~b}$ & $12.01 \pm 1.17 a b$ & $13.17 \pm 0.75 a$ & $11.68 \pm 0.93 a$ & $12.66 \pm 0.78 a$ & $13.07 \pm 0.74 a$ \\
\hline Exchangeable $\mathrm{K}\left(\mathrm{cmol} \cdot \mathrm{kg}^{-1}\right)$ & $0.71 \pm 0.05 \mathrm{ab}$ & $0.70 \pm 0.03 b$ & $0.76 \pm 0.05 a$ & $0.72 \pm 0.05 a$ & $0.86 \pm 0.28 a$ & $0.72 \pm 0.07 a$ \\
\hline Soil moisture (\%) & & & & $7.66 \pm 0.61 b$ & $13.28 \pm 0.52 a$ & $13.95 \pm 0.60 \mathrm{a}$ \\
\hline Soil quality index & $29.14 \pm 0.36 a$ & $27.42 \pm 0.33 b$ & $26.72 \pm 0.64 b$ & $27.59 \pm 0.29 a$ & $26.14 \pm 0.29 b$ & $24.33 \pm 0.97 b$ \\
\hline
\end{tabular}

Mean values \pm SE $(n=5)$ are shown. FR, SR and TR represent the rhizosphere of seedling plantations, first generation coppice plantations and second generation coppice plantations, respectively; FNR, SNR and TNR represent bulk soil of seedling plantations, first generation coppice stands and second generation coppice stands, respectively. $N$ nitrogen, $C$ carbon, $P$ phosphorus, $C / N$ carbon and nitrogen ratio, $C / P$ carbon and phosphorus ratios, $N / P$ nitrogen and phosphorus ratios, $\mathrm{NO}_{3}{ }^{-}-\mathrm{N}$ nitrate nitrogen, $\mathrm{NH}_{4}{ }^{+}-\mathrm{N}$ ammonium nitrogen, $A$. $\mathrm{N}$ available nitrogen, $A$. $P$ available phosphorus, SOM soil organic carbon. Different lowercase letters indicate significant differences in soil properties among the bulk soil or rhizosphere in different $R$. pseudoacacia plantations $(p<0.05)$

\section{Relative abundance of rhizobium in seedling and coppice plantations}

The relative abundance of Rhizobium in both bulk soil and rhizosphere in second-generation coppice stands was significantly higher than in seedling and firstgeneration coppice stands. The relative abundance of Rhizobium was the highest in the rhizosphere of $\mathrm{T}$ stands $(0.32 \%)$, while the lowest was found in the bulk soil of seedling (F) stands $(0.11 \%)$. Moreover, the difference in Rhizobium abundance between rhizosphere soil and bulk soil was significant in seedling plantations $(p=0.002)$, while there was no difference in coppice plantations (Fig. 2).

\section{Bacterial community composition in seedling and coppice plantations}

The results showed five replicates usually clustered closely (Fig. 3). The first and second PCA axes revealed
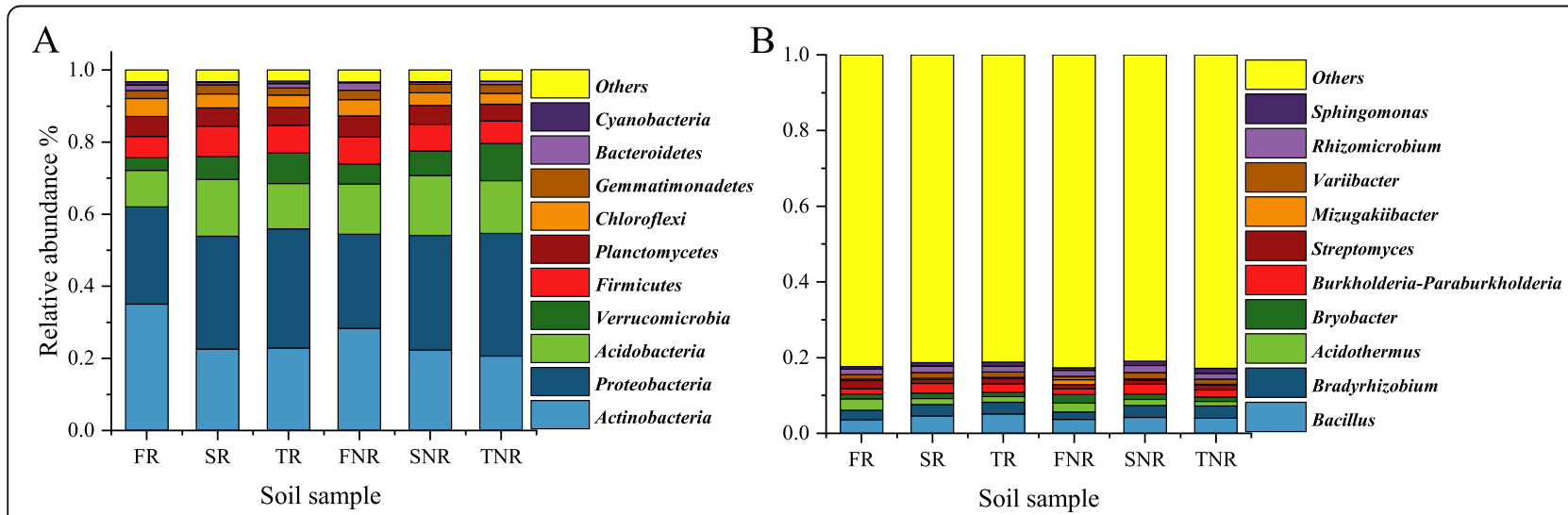

Fig. 1 Relative abundance of the dominant bacteria phylum and genus among the soil bacterial phyla via sequencing of 165 rRNA gene amplicons in bulk soil and rhizosphere of different stands 
Table 2 Differences in bacterial a-diversity in the rhizosphere and bulk soil between seedling and coppice R. pseudoacacia plantations

\begin{tabular}{lllllll}
\hline & FR & SR & TR & FNR & SNR & TNR \\
\hline Shannon & $9.2205 \pm 0.0473 \mathrm{a}$ & $9.1055 \pm 0.0119 \mathrm{bc}$ & $9.1803 \pm 0.0155 \mathrm{ab}$ & $9.2186 \pm 0.0482 \mathrm{a}$ & $9.0159 \pm 0.0329 \mathrm{c}$ & $9.0336 \pm 0.0339 \mathrm{c}$ \\
Simpson & $0.9954 \pm 0.0001 \mathrm{a}$ & $0.9949 \pm 0.0001 \mathrm{ab}$ & $0.9945 \pm 0.0002 \mathrm{~b}$ & $0.9954 \pm 0.0003 \mathrm{a}$ & $0.9945 \pm 0.0002 \mathrm{~b}$ & $0.9934 \pm 0.0004 \mathrm{c}$ \\
\hline
\end{tabular}

that the rhizosphere- and bulk soil-associated bacterial microbiota were inhomogeneous at phylum $(12.77 \%$ and $8.23 \%$, respectively; Fig. 3a) and genus $(17.21 \%$ and $13.16 \%$, respectively; Fig. $3 \mathrm{~b}$ ) levels. The soil layer and plantation type rendered a significant effect on bacterial community composition. The similarities in bacterial community composition within rhizosphere and bulk soil were lower in seedling plantations than in coppice plantations (Fig. 3).

We found that $\mathrm{C}, \mathrm{N}, \mathrm{SOM}, \mathrm{NO}_{3}{ }^{-} \mathrm{N}$ and $\mathrm{A}$. P were positively correlated with bacterial community composition by Mantel tests at both phylum and genus levels (Table 3). Spearman correlation analysis of the relationships between soil properties and bacterial community at the phylum (Fig. 4a) and genus levels (Fig. 4b) also confirmed the positive correlation between bacterial communities and nutrient concentrations. At the phylum level, SOM, $\mathrm{NO}_{3}{ }^{-}-\mathrm{N}$, and A. P were significantly and negatively correlated with Proteobacteria $(r=-0.66$, $p=0.000 ; r=-0.62, p=0.000$ and $r=-0.73, p=0.000$, respectively), and were significantly and positively correlated with Actinobacteria $(r=0.71, p=0.000 ; r=0.64$, $p=0.000$ and $r=0.59, p=0.001$, respectively), but there was no significant correlation with Acidobacteria. At the genus level, Acidothermus, Bryobacter and Mizugakiibacter were significantly and positively correlated with SOM, $\mathrm{NO}_{3}{ }^{-}-\mathrm{N}$, and A. P $(r=0.65,0.62$ and $0.68 ; p=$ $0.000, p=0.000$ and $p=0.000$, respectively). Bacterial

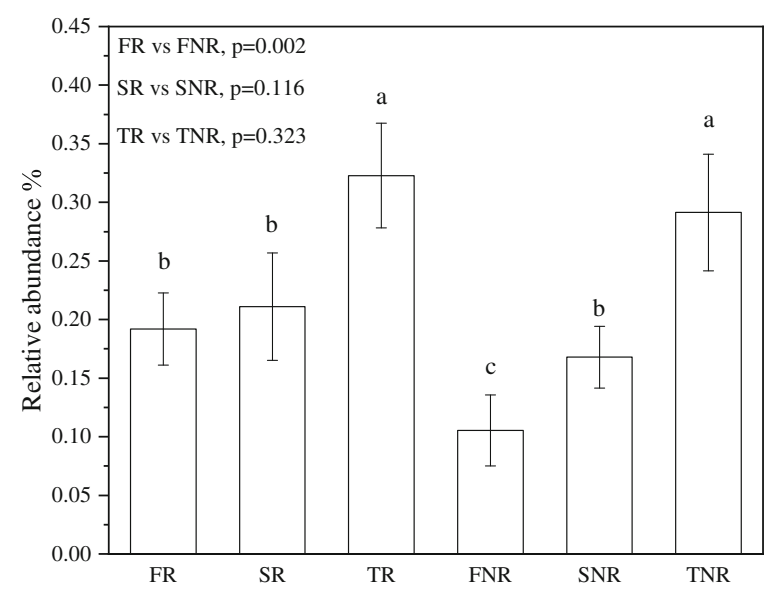

Fig. 2 Differences in the relative abundance of Rhizobium between the rhizosphere and bulk soil seedling and coppice stands. $a=0.05$ taxa were also more correlated with soil nutrient concentrations at the genus level than at the phylum level.

$\mathrm{N}, \mathrm{C}, \mathrm{SOM}$ and $\mathrm{NO}_{3}{ }^{-}-\mathrm{N}$, the most significant factors for bacterial community composition according to the Mantel test results $(p<0.001$, at the phylum and genus levels), were selected for variance partitioning canonical correspondence analysis (VPA), to quantify the relative contributions of soil properties to bacterial community structure. The soil properties explained $75.46 \%$ of the observed variation, leaving $24.54 \%$ of the variation unexplained. Among them, $\mathrm{C}, \mathrm{N}, \mathrm{SOM}$ and $\mathrm{NO}_{3}{ }^{-} \mathrm{N}$ explained $9.28 \%, 0.00 \%, 3.52 \%$ and $15.12 \%$, respectively. Thus, $\mathrm{NO}_{3}{ }^{-}-\mathrm{N}$, but not $\mathrm{N}$, was the most important factor in shaping the bacterial community structure (Fig. 5).

\section{Discussion}

Conversion from seedling to coppice stands reduced soil quality

Forest conversion has a great impact on plant and soil characteristics, altering soil bacterial community structure, soil nutrients and plant diversity and composition (Wang et al., 2011; Zhao et al. 2019). Previous studies have shown that $R$. pseudoacacia may induce significant changes on several physical and chemical properties of the soil (Khan et al. 2010; Liu et al. 2018b; Du et al. 2019). In $R$. pseudoacacia coppice stands, intra-specific competition increases because of the high stem density, which may result in differences in microclimatic and ecological conditions as compared to seedling stands. In this regard, our results provide incremental knowledge to previous research by further showing that the conversion from seedling to coppice stands reduced soil quality (Table 1), consistently with the findings of Johnson and Curtis, 2001) and Luo (2006). Therefore, it supports our first hypothesis inasmuch as $R$. pseudoacacia is a $\mathrm{N}_{2}$-fixing species with a strong nitrogen fixation ability. However, our results showed that soil $\mathrm{N}\left(\mathrm{N}, \mathrm{NO}_{3}{ }^{-}-\mathrm{N}\right.$ and A.N) concentrations declined in coppice stands. It possibly indicates that the nitrogen fixation ability of $R$. pseudoacacia coppice decreased to a certain extent, and the $\mathrm{N}$ mineralization rate was significantly lower compared to seedling (F) stands (unpublished data). The main reason may be that the conversion decreased the net primary production and aboveground biomass and productivity (Liao et al. 2012). Specially, the coppice stands had lower stand productivity than the stand 

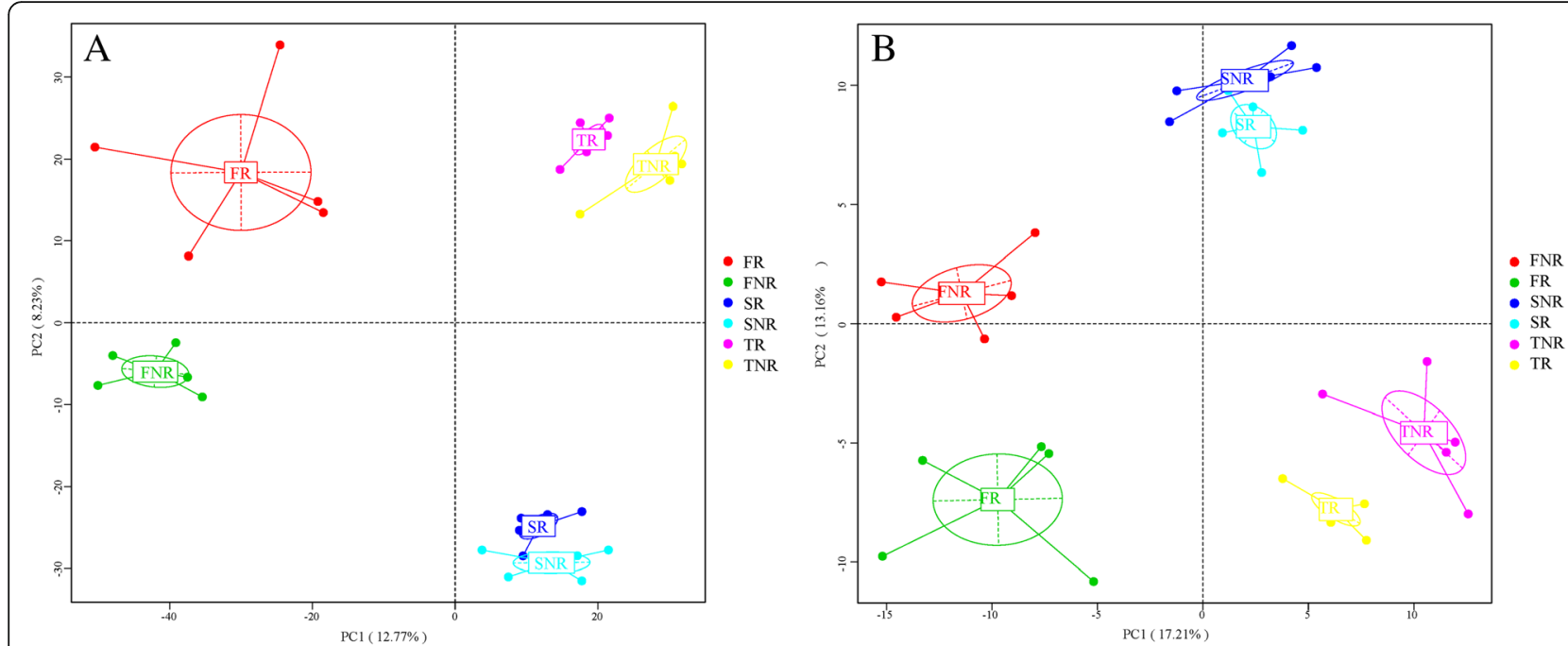

Fig. 3 Principal Component Analysis (PCA) (Bray-Curtis distance) among bulk soil and rhizosphere bacterial communities at phylum a and genus b level. Red and green represent the bacterial community of bulk soil and rhizosphere in seedling plantations ( $F$ ); blue and cyan represent the bacterial community of bulk soil and rhizosphere in first-generation coppice stands (S); pink and yellow represent the bacterial community of bulk soil and rhizosphere in second-generation coppice stands (T)

developed from seedlings (Fig. S2), which could contribute to modifying soil structure and lead to less inputs and more losses of soil nutrients (Zheng et al. 2005), finally affecting the absorption of $\mathrm{N}$ by trees (Zhang et al. 2018b). Additionally, we found that the greater soil moisture content occurred in coppice plantations (13.95\%), which might reduce root and microbial activity (Banerjee et al. 2016), then reduce the soil total $\mathrm{N}$ concentration, $\mathrm{N}$ storage, $\mathrm{N}$ cycling and availability (Wang et al. 2010).

Table 3 Mantel-test between bacteria phylum and genus and soil properties

\begin{tabular}{llllll}
\hline Soil properties & \multicolumn{1}{l}{ Phylum } & & Genus & \\
\cline { 2 - 3 } & $\boldsymbol{r}$ & $\boldsymbol{p}$ & & $\boldsymbol{r}$ & $\boldsymbol{p}$ \\
\hline $\mathrm{N}$ & 0.495 & 0.001 & 0.505 & 0.001 \\
$\mathrm{C}$ & 0.4433 & 0.001 & 0.4419 & 0.001 \\
$\mathrm{P}$ & 0.08502 & 0.07 & 0.04408 & 0.236 \\
$\mathrm{C} / \mathrm{N}$ & 0.008762 & 0.499 & 0.04093 & 0.665 \\
$\mathrm{C} / \mathrm{P}$ & 0.1329 & 0.046 & 0.09815 & 0.106 \\
$\mathrm{~N} / \mathrm{P}$ & 0.1254 & 0.044 & 0.09049 & 0.13 \\
$\mathrm{SOM}$ & 0.4002 & 0.001 & 0.3239 & 0.001 \\
$\mathrm{NO}_{3}{ }^{-}{ }^{-\mathrm{N}}$ & 0.5758 & 0.001 & 0.5383 & 0.001 \\
$\mathrm{NH}_{4}{ }^{+}-\mathrm{N}$ & 0.2009 & 0.016 & 0.1892 & 0.017 \\
A.N & 0.2144 & 0.007 & 0.2028 & 0.015 \\
A.P & 0.4528 & 0.001 & 0.4239 & 0.001 \\
Exchangeable Ca & 0.03213 & 0.308 & 0.04071 & 0.285 \\
Exchangeable Mg & 0.1988 & 0.017 & 0.187 & 0.033 \\
Exchangeable K & 0.06525 & 0.767 & 0.07211 & 0.764 \\
\hline
\end{tabular}

Due to root exudations, microbiota activity, and plant absorption, which may lead to the accumulation of nutrients in the rhizosphere, the micro-environments between the rhizosphere and bulk soil may differ markedly (Philippot et al. 2013). Our results showed that N and C contents in bulk soil were higher than those in the rhizosphere, but the concentrations of other nutrients (e.g. SOM, $\mathrm{NO}_{3}{ }^{-}-\mathrm{N}$ and A.P) were lower in the bulk soil than in the rhizosphere (Table 1). These results are consistent with previous research (Chaudhary et al. 2015). One possible main reason is that plant roots directly uptake less available nutrients and reduce carbon loss in the rhizosphere (Jones et al. 2009), and they could also adapt to changes in soil nutrient availability through the elastic distribution of underground roots (Bardgett et al. 2014). The consumption of $\mathrm{N}$ for tree growth, the strong physiological metabolism function of root system and the activity of rhizosphere microorganisms drive the transformation of $\mathrm{N}$ to $\mathrm{A}$. $\mathrm{N}$, and this may be the reason why we found that rhizosphere soil had lower $\mathrm{N}$ content and higher $\mathrm{A}$. $\mathrm{N}$ content (Table 1).

\section{Conversion from seedling to coppice stands altered the structure of bacterial communities}

Changes in forest community types can affect soil microbial structure (Cardenas et al. 2015) and $\alpha$-diversity (Vitali et al. 2016). Our results showed that Shannon and Simpson indices declined from seedling to coppice stands (Table 2). These shifts can be accompanied by changes in bacterial functional activity (Kaiser et al. 2014), contributing to one of the reported changes of soil nutrients (Zhao et al. 2018). Previous research 


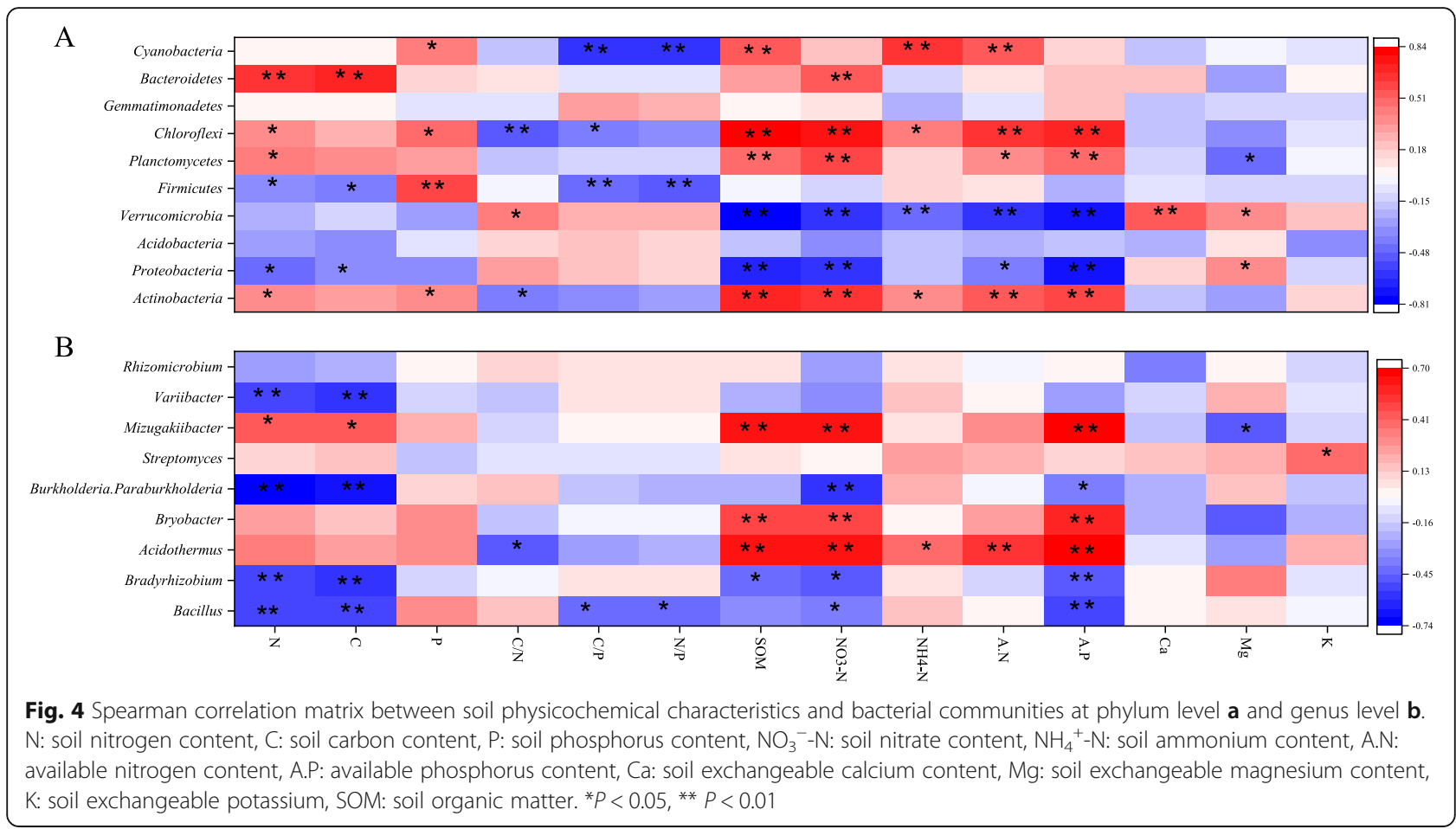

(Shi et al. 2016) found that rhizosphere microbes displayed higher levels of interactions than bulk soil microbes. However, we found that the bacterial community structures of bulk soil and rhizosphere were not significantly different in coppice plantations (Fig. 3), which supports the hypothesis that the bacterial community structures of rhizosphere soil and bulk soil tend to be homogeneous. One possible explanation is the higher moisture content in coppice stands, which could better meet the needs of the microbial community (Cui et al. 2019). Another complementary possible reason may be that root activity was weaker in coppice stands due to their lower productivity (Table S2). Thus, both soil environment and root activity may be responsible for the consistency of the bacterial community composition between the rhizosphere and bulk soil in coppice plantations.

At the phylum level, the three most abundant bacteria in both rhizosphere and bulk soil samples were Proteobacteria, Actinobacteria and Acidobacteria, in accordance with the findings of Fonseca et al. (2018). The relative abundance of Actinobacteria and Verrucomocrobia decreased from F to $\mathrm{T}$ stands, while Proteobacteria showed an opposite trend (Fig. 1a). A possible explanation for this result is that the Proteobacteria are generally fast-growing $r$-strategists with the ability to use a wide range of root-derived carbon substrates (Philippot et al. 2013). Thus, the decline in soil quality would drive

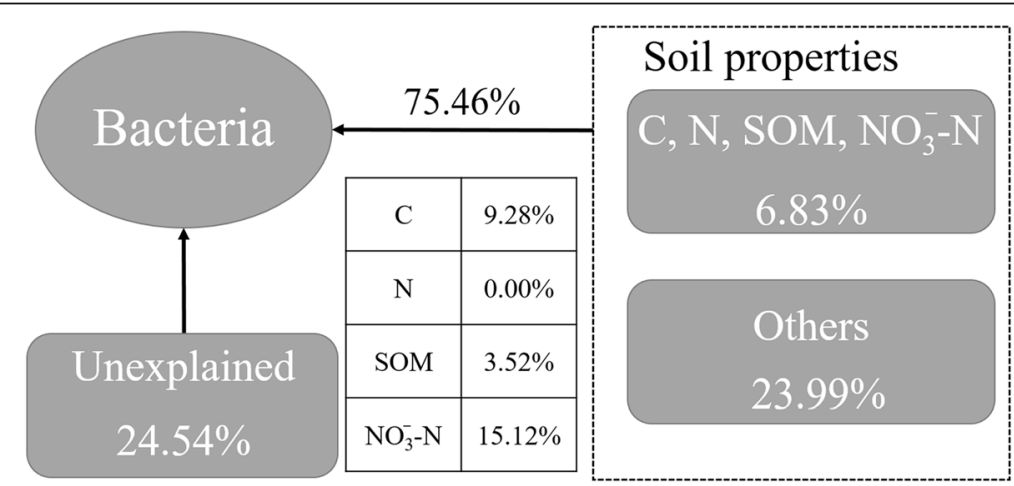

Fig. 5 Variance partition analysis (VPA) of the effects of soil properties on the bacterial community structure. Soil properties include C, N, SOM and $\mathrm{NO}_{3}{ }^{-} \mathrm{N}$ and interaction among them. "Others" include other soil properties, such as $\mathrm{P}, \mathrm{NH}_{4}{ }^{+} \mathrm{N}$, $\mathrm{Ca}$ and so on 
Proteobacteria to acquire more abundant carbon sources to sustain growth, but the underlying mechanisms need to be further explored. The main function of Actinobacteria is to absorb nutrients and excrete metabolic products, which results in the decline of soil quality (Wang et al., 2007). At the genus level, the relative abundance of Bacillus and Bradyrhizobium increased from $\mathrm{F}$ to $\mathrm{T}$ stands, while Acidothermus and Bryobacter showed an opposite trend (Fig. 1b). Therefore, the proportion of dominant species changed, resulting in bacterial community composition homogeneity of bulk soil and rhizosphere in coppice stands. Such a homogenization in community composition is predicted to alter ecosystem function and reduce ecosystem resilience to disturbance (Olden et al. 2004) and result in a net loss of diversity (Rodrigues et al. 2013).

\section{Conversion from seedling to coppice stands increased the relative abundance of rhizobium}

$R$. pseudoacacia can increase the availability of soil inorganic N, presumably because of Robinia's ability to fix $\mathrm{N}_{2}$ by association with Rhizobium (Zhang et al. 2019), which is the main source of nitrogen in Robinia stands (Papaioannou et al. 2016). Our results showed that the relative abundance of Rhizobium increased from seedling to coppice stands, which was against our third hypothesis. The reason may be that most of the Rhizobium bacteria are free-living individuals in the soil, resulting in the decrease of the symbiotic fixation of atmospheric $\mathrm{N}$ within the root nodules of legume hosts (Joëlle et al. 2010; Wang et al. 2018b). Another plausible reason may be that the biological nitrogen fixation requires an expenditure of more C and P (Liu and Deng 1991; Tye and Drake 2011). Deficit of $C$ and $P$ in $R$. pseudoacacia stands would decrease and, finally, inhibit symbiotic fixation of atmospheric nitrogen. In the meantime, some study has reported that soil nitrogen-fixing bacterial communities can increase the level of soil available $\mathrm{N}$ via biological N-fixation (Wang et al. 2018a), while our results showed an opposite trend. This may be related to the decline of soil $\mathrm{C}$ and $\mathrm{N}$ or to the reduced amount of litter biomass (Cao et al. 2018).

\section{Relationships between bacterial community and soil properties}

Soil bacterial communities are strongly influenced by abiotic controls (Thoms and Gleixner 2013), such as total organic carbon (TOC), total nitrogen (TN) (Zhou et al. 2012; Lazzaro et al. 2017). And, vice versa, shifts in microbial communities can affect multiple environmental factors (Fonseca et al. 2018), including potential negative impacts on soil health and plant nutrient acquisition. Therefore, environmental conditions mainly affect the diversity of bacterial communities by changing the physical and chemical properties of the soil (Zhang et al. 2018b). In this study, we found that bacterial communities in both the rhizosphere and bulk soil were strongly influenced by soil C, N, SOM, A. P and $\mathrm{NO}_{3}{ }^{-}-\mathrm{N}$ (Table 2, Figs. 4 and 5), which supports our second hypothesis, i.e., that nutrient availability plays an important role in shaping bacterial community. $\mathrm{C}$ and $\mathrm{N}$ contents exhibited a strong significantly positive correlation with $\mathrm{Bac}$ teroidetes, and a negative correlation with Proteobacteria and Firmicutes, whereas no correlation with Actinobacteria and Acidobacteria (Fig. 4), which was consistent with the results reported by Fierer (2007) and Zhao (2018). Proteobacteria are considered to be rhizosphericplant-promoting bacteria that can influence $C$ accumulation (Ren et al. 2016), and have a significantly positive effect on $\mathrm{C}$ fractions. However, our results showed an opposite trend. The reason may be that Bacteroidetes can influence the rate of $\mathrm{C}$ mineralization and fix atmospheric nitrogen in symbiosis (Fierer et al. 2007).

Soil bacterial community can increase soil $\mathrm{NO}_{3}{ }^{-} \mathrm{N}$ content (Zhang et al. 2015; Lazzaro et al. 2017). The conversion from seedling to coppice stands altered the structure of the soil bacterial community and decreased soil resource availability (Zhang et al. 2017), which also partly supports the hypothesis that nutrient availability plays an important role in shaping the bacterial community. In this study, we found that bacterial communities in both the rhizosphere and bulk soil were strongly influenced by soil $\mathrm{NO}_{3}{ }^{-}-\mathrm{N}$ (Fig. 5), similarly to the results of Liu et al. (2018a). $\mathrm{NO}_{3}{ }^{-}-\mathrm{N}$ may play an important role in shaping bacterial communities in $R$. pseudoacacia plantations. Nitrogen in soil can be decomposed by bacteria to promote $\mathrm{N}$ absorption by trees. All $\mathrm{N}$ transformation and uptake processes are correlated with soil carbon resources and regulated by soil microbes (Geisseler et al. 2010). Our results showed that $\mathrm{C}$ and $\mathrm{NO}_{3}{ }^{-}-\mathrm{N}$ contents in the coppice stands were lower than those in seedling plantations, leading to inhibition of microbial activity.

\section{Conclusions}

Our research revealed three important findings for assessing the impacts on soil habitat arising from the conversion of $R$. pseudoacacia seedling plantations to coppice stands. First, we found that this conversion can negatively affect soil properties such as total carbon, total nitrogen, nitrate and soil organic matter, and the conversion could also alter soil bacterial community composition. Second, we found that $\mathrm{NO}_{3}{ }^{-} \mathrm{N}$ is the most important factor in shaping soil bacterial structure in this ecosystem. Additionally, the stand conversion increased the relative abundance of Rhizobium, while the soil $\mathrm{N}$ and available $\mathrm{N}$ decreased, suggesting that the activity of Rhizobium was restricted. Finally, we found 
higher homogeneity of the bacterial community composition in bulk soil and rhizosphere in coppice stands due to the higher moisture content and weaker root activity in coppice stands.

In conclusion, we confirmed the hypotheses that (1) the changes caused by the conversion of seedling to coppice stands can lead to decline in soil quality, and to alterations in soil bacterial community composition, and (2) nutrient availability, in particular $\mathrm{NO}_{3}{ }^{-}-\mathrm{N}$, plays an important role in shaping the bacterial community. Nevertheless, we did not find evidence supporting the hypothesis (3) that the relative abundance of Rhizobium decreases in coppice plantations. Further research on N cycling including $\mathrm{N}$ mineralization, nitrification, anaerobic ammonium oxidation, denitrification and nitrogen fixation, as well as understory cover changes resulting from stand conversion from seedling to coppice stands can help to better assess this phenomenon.

\section{Supplementary Information}

The online version contains supplementary material available at https://doi. org/10.1186/s40663-021-00296-x.

Additional file 1: Figure S1 Sketch of sampling design for each replicate site in $\mathrm{R}$. pseudoacacia seedling and coppice stands (three sites in total representing seedling stands, and the first- and secondgeneration coppice stands, respectively). Figure S2 Annual stand productivity of seedling and coppice stands

\section{Acknowledgements}

We are very grateful to all the students who assisted with data collection and the experiments. We also thank three anonymous reviewers for helpful comments and suggestions on this paper.

\section{Authors' contributions}

Conceived and designed the study: $K \mathrm{~L}, \mathrm{XH}, \mathrm{CR}$ L. Collected data and samples in the field: $K L, G S, W X S, Y K Z, X Z Z$. Processed samples in the lab: $K L, G$ S. Analyzed the data: $K L$ and $X H$. Wrote the paper: $K L, R Q N$ and $S$ D-M. All authors read and approved the final manuscript.

\section{Funding}

This work was financially supported by the Special Fund for Forestry Scientific Research in the Public Interest No. 201504406, the National Natural Science Foundation of China (Nos. 31570705, 31500362, 31700553), the Shandong Provincial Natural Science Foundation, China (No. ZR2016CP01), the Project of Shandong Province Higher Educational Science and Technology Program (No. J16LF09), and China Scholarship Council (No. 201809135006). The contribution of S. de-Miguel was supported by the Spanish Ministry of Economy and Competitivity (MINECO) (Grant No. RTI2018-099315-A-100) and by a Serra-Húnter Fellowship provided by the Generalitat of Catalonia.

\section{Availability of data and materials}

The datasets used and/or analysed during the current study are available from the corresponding author on reasonable request.

\section{Ethics approval and consent to participate}

Not applicable.

\section{Consent for publication}

Not applicable.

\section{Competing interests}

The authors declare that they have no competing interests.

\section{Author details}

${ }^{1}$ Mountain Tai Forest Ecosystem Research Station of State Forestry Administration / Key Laboratory of State Forestry Administration for Silviculture of the Lower Yellow River, Tai'an 271018, Shandong, China. ${ }^{2}$ Department of Crop and Forest Sciences, University of Lleida, Av. Alcalde Rovira Roure 191, E25198 Lleida, Spain. ${ }^{3}$ Joint Research Unit CTFC AGROTECNIO, Av. Alcalde Rovira Roure 191, E25198 Lleida, Spain. ${ }^{4}$ Mount Tai Scenic Spot Management Committee, Tai'an 271000, Shandong, China.

Received: 10 July 2020 Accepted: 19 February 2021

Published online: 03 March 2021

\section{References}

Balota EL, Yada IF, Amaral H, Nakatani AS, Dick RP, Coyne MS (2013) Long-term land use influences soil microbial biomass $\mathrm{P}$ and $\mathrm{S}$, phosphatase and arylsulfatase activities, and S mineraliztion in a Brazilian oxisol. Land Degrad Dev 25(4):397-406. https://doi.org/10.1002/ldr.2242

Banerjee S, Helgason B, Wang L, Winsley T, Ferrari BC, Siciliano SD (2016) Legacy effects of soil moisture on microbial community structure and $\mathrm{N}_{2} \mathrm{O}$ emissions. Soil Biol Biochem 95:40-50. https://doi.org/10.1016/j.soilbio.201 5.12 .004

Bardgett RD, Mommer L, De Vries FT (2014) Going underground: root traits as drivers of ecosystem processes. Trend Ecol Evol 29(12):692-699. https://doi. org/10.1016/j.tree.2014.10.006

Berthold D, Vor T, Beese F (2009) Effects of cultivating black locust (Robinia pseudoacacia L.) on soil chemical properties in Hungary. Forstarchiv 80(6): 307-313. http://media.repro-mayr.de/77/548177.pdf. Accessed 19 May 2020

Buzhdygan OY, Rudenko SS, Kazanci C, Patten BC (2016) Effect of invasive black locust (Robinia pseudoacacia L.) on nitrogen cycle in floodplain ecosystem. Ecol Model 319:170-177. https://doi.org/10.1016/j.ecolmodel.2015.07.025

Cao Y, Zhang P, Chen Y (2018) Soil C:N:P stoichiometry in plantations of N-fixing black locust and indigenous pine, and secondary oak forests in Northwest China. J Soils Sediments 18(4):1478-1489. https://doi.org/10.1007/s11368-01 7-1884-0

Caporaso JG, Kuczynski J, Stombaugh J, Bittinger K, Bushman FD, Costello EK, Fierer N, Pena AG, Goodrich JK, Gordon JI, Huttley GA, Kelley ST, Knights D, Koenig JE, Ley RE, Lozupone CA, McDonald D, Muegge BD, Pirrung M, Reeder J, Sevinsky JR, Turnbaugh PJ, Walters WA, Widmann J, Yatsunenko T, Zaneveld J, Knight R (2010) QIIME allows analysis of high-throughput community sequencing data. Nat Method 7:335-336. https://doi.org/10.1038/ nmeth.f.303

Cardenas E, Kranabetter JM, Hope G, Maas KR, Hallam S, Mohn WW (2015) Forest harvesting reduces the soil metagenomic potential for biomass decomposition. ISME J 9:2465-2476. https://doi.org/10.1038/ismej.2015.57

Chaudhary DR, Gautam RK, Yousuf B, Mishra A, Jha B (2015) Nutrients, microbial community structure and functional gene abundance of rhizosphere and bulk soils of halophytes. Appl Soil Ecol 91:16-26. https://doi.org/10.1016/j.a psoil.2015.02.003

Chen C, Fang X, Xiang W, Lei P, Ouyang S, Kuzyakov Y (2020) Soil-plant costimulation during forest vegetation restoration in a subtropical area of southern China. Forest Ecosyst 7:1-17. https://doi.org/10.1186/s40663-02000242-3

Chen QL, An XL, Zhu YG, Su JQ, Gillings MR, Ye ZL, Cui L (2017) Application of struvite alters the antibiotic resistome in soil, rhizosphere, and phyllosphere. Environ Sci Technol 51(14):8149-8157. https://doi.org/10.1 021/acs.est.7b01420

Cierjacks A, Kowarik I, Joshi J, Hempel S, Ristow M, Von LM, Weber E (2013) Biological Flora of the British Isles: Robinia pseudoacacia. J Ecol 101:16231640. https://doi.org/10.1111/1365-2745.12162

Crawford KM, Bauer JT, Comita LS, Eppinga MB, Johnson DJ, Mangan SA, Queenborough SA, Strand AE, Suding KN, Umbanhowar J, Bever JD (2019) When and where plant-soil feedback may promote plant coexistence: a meta-analysis. Ecol Lett 22(8):1274-1284. https://doi.org/10.1111/ele.13278

Cui YX, Bing HJ, Fang LC, Wu YH, Yu JL, Shen GT, Jiang M, Wang X, Zhang XC (2019) Diversity patterns of the rhizosphere and bulk soil microbial communities along an altitudinal gradient in an alpine ecosystem of the eastern Tibetan plateau. Geoderma 338:118-127. https://doi.org/10.1016/j. geoderma.2018.11.047

Du B, Pang J, Hu B, Allen DE, Bell TL, Pfautsch S, Netzer F, Dannenmann M, Zhang SX, Rennenberg H (2019) $\mathrm{N}_{2}$-fixing black locust intercropping improves ecosystem nutrition at the vulnerable semi-arid loess plateau 
region, China. Sci Total Environ 688:333-345. https://doi.org/10.1016/j. scitotenv.2019.06.245

Fierer N, Bradford MA, Jackson RB (2007) Toward an ecological classification of soil bacteria. Ecology 88:1354-1364. https://doi.org/10.1016/j.jglr.2009.01.002

Fonseca JP, Hoffmann L, Cabral BCA, Dias VHG, Miranda MR, Azevedo MAC, Boschiero C, Bastos WR, Silva R (2018) Contrasting the microbiomes from forest rhizosphere and deeper bulk soil from an Amazon rainforest reserve. Gene 642:389-397. https://doi.org/10.1016/j.gene.2017.11.039

Geisseler D, Horwath WR, Joergensen RG, Ludwig B (2010) Pathways of nitrogen utilization by soil microorganisms-a review. Soil Biol Biochem 42:2058-2067. https://doi.org/10.1016/j.soilbio.2010.08.021

Geng B, Wang HT, Wang YP, Xue BJ, Li WQ (2013) Comparative study of coppice and seeding forest of Robinia pseudoacacia L. Sci Soil Water Conserv 11(2): 59-64. https://doi.org/10.16843/j.sswc.2013.02.010

Guo SJ, Xu YD, He C, Wu SJ, Ren CJ, Han XH, Feng YZ, Ren GX, Yang GH (2019) Differential responses of soil quality in revegetation types to precipitation gradients on the loess plateau. Agric Forest Meteorol 276:107622. https://doi. org/10.1016/j.agrformet.2019.107622

Ji L, Zhang Q, Fu X, Zheng L, Dong J, Wang J, Guo S (2019) Feedback of airborne bacterial consortia to haze pollution with different PM2.5 levels in typical mountainous terrain of Jinan, China. Sci Total Environ 695:133912. https://doi. org/10.1016/j.scitotenv.2019.133912

Jiao S, Chen W, Wang J, Du N, Li Q, Wei G (2018) Soil microbiomes with distinct assemblies through vertical soil profiles drive the cycling of multiple nutrients in reforested ecosystems. Microbiome 6(1):1-13. https://doi.org/1 0.1186/s40168-018-0526-0

Joëlle F, Lesuffleur F, Stéphanie M, Cliquet JB (2010) Nitrogen rhizodeposition of legumes A review. Agron Sustain Dev 30(1):57-66. https://doi.org/10.1051/a gro/2009003

Johnson DW, Curtis PS (2001) Effects of forest management on soil C and N storage: meta-analysis. Forest Ecol Manag 140:227-238. https://doi.org/10.101 6/S0378-1127(00)00282-6

Jones DL, Nguyen C, Finlay RD (2009) Carbon flow in the rhizosphere: carbon trading at the soil-root interface. Plant Soil 321(1/2):5-33. https://doi.org/10.1 007/s11104-009-9925-0

Kaiser C, Franklin O, Dieckmann U, Richter A (2014) Microbial community dynamics alleviate stoichiometric constraints during litter decay. Ecol Lett 17: 680-690. https://doi.org/10.1111/ele.12269

Khan B, Ablimit A, Mahmood R, Qasim M (2010) Robinia pseudoacacia leaves improve soil physical and chemical properties. J Arid Land 4:266-271. http:// jal.xjegi.com/CN/10.3724/SP.J.1227.2010.00266. Accessed 19 May 2020

Lazzaro L, Mazza G, d'Errico G, Fabiani A, Giuliani C, Inghilesi AF, Lagomarsino A, Landi S, Lastrucci L, Pastorelli R, Roversi PF, Torrini G, Tricarico E, Foggi B (2017) How ecosystems change following invasion by Robinia pseudoacacia: insights from soil chemical properties and soil microbial, nematode, microarthropod and plant communities. Sci Total Environ 622-623:15091518. https://doi.org/10.1016/j.scitotenv.2017.10.017

Lee CS, Cho HJ, Yi H (2004) Stand dynamics of introduced black locust (Robinia pseudoacacia L.) plantation under different disturbance regimes in Korea. Forest Ecol Manag 189(1-3):281-293. https://doi.org/10.1016/j. foreco.2003.08.012

Liao C, Luo Y, Fang C, Chen J, Li B (2012) The effects of plantation practice on soil properties based on the comparison between natural and planted forests: a meta-analysis. Glob Ecol Biogeogr 21(3):318-327. https://doi.org/1 0.1111/j.1466-8238.2011.00690.x

Liu D, Huang Y, Sun H, An S (2018b) The restoration age of Robinia pseudoacacia plantation impacts soil microbial biomass and microbial community structure in the loess plateau. Catena 165:192-200. https://doi.org/10.1016/j.catena.201 8.02 .001

Liu GF, Deng TX (1991) Mathematical model of the relationship between nitrogen-fixation by black locust and soil conditions. Soil Biol Biochem 23(1): 1-7. https://doi.org/10.1016/0038-0717(91)90155-D

Liu JL, Dang P, Gao Y, Zhu HL, Zhu HN, Zhao F, Zhao Z (2018a) Effects of tree species and soil properties on the composition and diversity of the soil bacterial community following afforestation. Forest Ecol Manag 427:342-349. https://doi.org/10.1016/j.foreco.2018.06.017

Luo YQ, Hui DF, Zhang DQ (2006) Elevated $\mathrm{CO}_{2}$ stimulates net accumulations of carbon and nitrogen in land ecosystems: a meta-analysis. Ecology 87:53-63. https://doi.org/10.1890/04-1724

Ma S, Verheyen K, Props R, Wasof S, Vanhellemont M, Boeckx P, Boon N, Frenne PD (2018) Plant and soil microbe responses to light, warming and nitrogen addition in a temperate forest. Funct Ecol 32(5):1293-1303. https://doi.org/1 $0.1111 / 1365-2435.13061$

Mantovani D, Veste M, Boldt-Burisch K, Fritsch S, Koning LA, Freese D (2015) Carbon allocation, nodulation, and biological nitrogen fixation of black locust (Robinia pseudoacacia L.) under soil water limitation. Ann Forest Res 58:1. https://doi.org/10.15287/afr.2015.420

Medina-Villar S, Rodríguez-Echeverría S, Lorenzo P, Alonso A, Pérez-Corona E, Castro-Díez P (2016) Impacts of the alien trees Ailanthus altissima (mill.) Swingle and Robinia pseudoacacia L. on soil nutrients and microbial communities. Soil Biol Biochem 96:65-73. https://doi.org/10.1016/j.soilbio.201 6.01 .015

Mendes R, Garbeva P, Raaijmakers JM (2013) The rhizosphere microbiome: significance of plant beneficial, plant pathogenic, and human pathogenic microorganisms. FEMS Microbiol Rev 37(5):634-663. https://doi.org/10.1111/1 574-6976.12028

Nelson DW, Sommers LE (1982) Total carbon, organic carbon, and organicmatter. In: Page AL, Miller RH, DR K (eds) Methods of soil analysis. American Society of Agronomy and Soil Science Society, Madison, pp. 101-129

Neumann D, Heuer A, Hemkemeyer M, Martens R, Tebbe CC (2014) Response of microbial communities to long-term fertilization depends on their microhabitat. FEMS Microbiol Ecol 86(1):71-84. https://doi.org/10.1111/15746941.12092

Olden JD, Poff NL, Douglas MR, Douglas ME, Fausch KD (2004) Ecological and evolutionary consequences of biotic homogenization. Trend Ecol Evol 19(1): 18-24. https://doi.org/10.1016/j.tree.2003.09.010

Papaioannou A, Chatzistathis T, Papaioannou E, Papadopoulos G (2016) Robinia pseudoacacia as a valuable invasive species for the restoration of degraded croplands. Catena 137:310-317. https://doi.org/10.1016/j.catena.2015.09.019

Peng H, Chen XR, Yu ZD (2003) Know-how on sivilculture of black locust plantation. J Soil Water Conserv 17(5):11-15. https://doi.org/10.3321/j.issn:1 009-2242.2003.05.004

Philippot L, Raaijmakers JM, Lemanceau P, Van PWH (2013) Going back to the roots: the microbial ecology of the rhizosphere. Nat Rev Microbiol 11:789799. https://doi.org/10.1038/nrmicro3109

Radtke A, Ambraß S, Zerbe S, Tonon G, Fontana V, Ammer C (2013) Traditional coppice forest management drives the invasion of Ailanthus altissima and Robinia pseudoacacia into deciduous forests. Forest Ecol Manag 291:308-317. https://doi.org/10.1016/j.foreco.2012.11.022

Reynolds HL, Haubensak KA (2009) Soil fertility, heterogeneity, and microbes: towards an integrated understanding of grassland structure and dynamics. Appl Veg Sci 12(1):33-44. https://doi.org/10.1111/j.1654-109X.2 009.01020.x

Rodrigues JL, Pellizari VH, Mueller R, Baek K, Jesus EDC, Paula FS, Mirzaa B, Jr GSH, Tsaie SM, Feiglf B, Tiedjeg JM, Bohannanc BJM, Nüssleind K (2013) Conversion of the Amazon rainforest to agriculture results in biotic homogenization of soil bacterial communities. PNAS 110(3):988-993. https:// doi.org/10.1073/pnas.1220608110

Sabo AE (2000) Robinia pseudoacacia invasions and control in North America and Europe. University of Minnesota, Department of Horticultural Science. Retrieved from the University of Minnesota Digital Conservancy. https://hdl. handle.net/11299/59729. Accessed 19 Feb 2020

Sasse J, Martinoia E, Northen T (2018) Feed your friends: do plant exudates shape the root microbiome? Trend Plant Sci 23:25-41. https://doi.org/10.1016/j.tpla nts.2017.09.003

Shi S, Nuccio EE, Shi ZJ, He Z, Zhou J, Firestone MK (2016) The interconnected rhizosphere: high network complexity dominates rhizosphere assemblages. Ecol Lett 19:926-936. https://doi.org/10.1111/ele.12630

Thoms C, Gleixner G (2013) Seasonal differences in tree species' influence on soil microbial communities. Soil Biol Biochem 66:239-248. https://doi.org/10.101 6/j.soilbio.2013.05.018

Tye DRC, Drake DC (2011) An exotic Australian Acacia fixes more N than a coexisting indigenous Acacia in a south African riparian zone. Plant Ecol 213: 251-257. https://doi.org/10.1007/s11258-011-9971-6

Vitali F, Mastromei G, Senatore G, Caroppo C, Casalone E (2016) Long lasting effects of the conversion from natural forest to poplar plantation on soil microbial communities. Microbiol Res 182:89-98. https://doi.org/10.1016/j. micres.2015.10.002

Vítková M, Müllerová J, Sádlo J, Pergl J, Pyšek P (2017) Black locust (Robinia pseudoacacia) beloved and despised: a story of an invasive tree in Central Europe. Forest Ecol Manag 384:287-302. https://doi.org/10.1016/j.foreco.201 6.10 .057 
Vitkova M, Tonika J, Mullerova J (2015) Black locust-successful invader of a wide range of soil conditions. Sci Total Environ 505:315-328. https://doi.org/10.101 6/j.scitotenv.2014.09.104

Wang C, Jiang K, Zhou J, Wu B (2018a) Solidago canadensis invasion affects soil $\mathrm{N}$-fixing bacterial communities in heterogeneous landscapes in urban ecosystems in East China. Sci Total Environ 631-632:702-713. https://doi. org/10.1016/j.scitotenv.2018.03.061

Wang F, Li Z, Xia H, Zou B, Ningyu LI, Liu J, Zhu WX (2010) Effects of nitrogenfixing and non-nitrogen-fixing tree species on soil properties and nitrogen transformation during forest restoration in southern China. Soil Sci Plant Nutr 56(2):297-306. https://doi.org/10.1111/j.1747-0765.2010.00454.x

Wang Q, Garrity GM, Tiedje JM, Cole JR (2007) Naive Bayesian classifier for rapid assignment of rRNA sequences into the new bacterial taxonomy. Appl Environ Microbiol 73(16):5261-5267. https://doi.org/10.1128/AEM.00062-07

Wang Q, Wang S, Yu X (2011) Decline of soil fertility during forest conversion of secondary forest to Chinese fir plantations in subtropical China. Land Degrad Dev 22:444-452. https://doi.org/10.1002/ldr.1030

Wang XL, Cui WJ, Feng XY, Zhong ZM, Li Y, Chen WX, Chen WF, Shao XM, Tian CF (2018b) Rhizobia inhabiting nodules and rhizosphere soils of alfalfa: a strong selection of facultative microsymbionts. Soil Biol Biochem 116:340350. https://doi.org/10.1016/j.soilbio.2017.10.033

Weidner S, Koller R, Latz E, Kowalchuk G, Bonkowski M, Scheu S, Jousset A (2015) Bacterial diversity amplifies nutrient-based plant-soil feedbacks. Funct Ecol 29: 1341-1349. https://doi.org/10.1111/1365-2435.12445

Williard KWJ, Dewalle DR, Edwards PJ (2005) Influence of bedrock geology and tree species composition on stream nitrate concentrations in midappalachian forested watersheds. Water Air Soil Pollut 160(1-4):55-76. https://doi.org/10.1007/s11270-005-3649-4

Yang B, Peng C, Zhu Q, Zhou X, Liu W, Duan M, Wang H, Liu ZH, Guo XY, Wang $M$ (2019) The effects of persistent drought and waterlogging on the dynamics of nonstructural carbohydrates of Robinia pseudoacacia $\mathrm{L}$. seedlings in Northwest China. Forest Ecosyst 6:23. https://doi.org/10.1186/s4 0663-019-0181-3

Yang H, Koide RT, Zhang Q (2016) Short-term waterlogging increases arbuscular mycorrhizal fungal species richness and shifts community composition. Plant Soil 404(1-2):373-384. https://doi.org/10.1007/s11104-016-2850-0

Yang K, Zhu JJ, Xu S, Zheng X (2018) Conversion from temperate secondary forests into plantations (Larix spp.): impact on belowground carbon and nutrient pools in northeastern China. Land Degrad Dev 29:4129-4139. https://doi.org/10.1002/ldr.3169

Yin L, Dijkstra FA, Wang P, Zhu B, Cheng W (2018) Rhizosphere priming effects on soil carbon and nitrogen dynamics among tree species with and without intraspecific competition. New Phytol 218:1036-1048. https://doi.org/1 $0.1111 /$ nph.15074

Zhang B, Zhang J, Liu Y, Shi P, Wei G (2018a) Co-occurrence patterns of soybean rhizosphere microbiome at a continental scale. Soil Biol Biochem 118:178186. https://doi.org/10.1016/j.soilbio.2017.12.011

Zhang D, Wang C, Li X, Yang X, Zhao L, Liu L, Zhu C, Li RH (2018b) Linking plant ecological stoichiometry with soil nutrient and bacterial communities in apple orchards. Appl Soil Ecol 126:1-10. https://doi.org/10.1016/j.apsoil.201 7.12.017

Zhang L, Wang J, Bai Z, Lv C (2015) Effects of vegetation on runoff and soil erosion on reclaimed land in an opencast coal-mine dump in a loess area. Catena 128:44-53. https://doi.org/10.1016/j.catena.2015.01.016

Zhang W, Liu W, Xu M, Deng J, Han X, Yang G, Feng Y, Ren G (2019) Response of forest growth to C: N: P stoichiometry in plants and soils during Robinia pseudoacacia afforestation on the loess plateau, China. Geoderma 337:280289. https://doi.org/10.1016/j.geoderma.2018.09.042

Zhang W, Lu Z, Yang K, Zhu J (2017) Impacts of conversion from secondary forests to larch plantations on the structure and function of microbial communities. Appl Soil Ecol 111:73-83. https://doi.org/10.1016/j.apsoil.201 6.11 .019

Zhao FZ, Bai L, Wang JY, Deng J, Ren CJ, Han XH, Yang GH, Wang J (2019) Change in soil bacterial community during secondary succession depend on plant and soil characteristics. Catena 173:246-252. https://doi.org/10.1016/j.ca tena.2018.10.024

Zhao FZ, Ren CJ, Zhang L, Han XH, Yang GH, Wang J (2018) Changes in soil microbial community are linked to soil carbon fractions after afforestation. Eur J Soil Sci 69:370-379. https://doi.org/10.1111/ejss.12525

Zheng H, Ouyang ZY, Wang XK, Fang ZG, Zhao TQ, Miao H (2005) Effects of regenerating forest cover on soil microbial communities: a case study in hilly red soil region, southern China. Forest Ecol Manag 217:244-254. https://doi. org/10.1016/j.foreco.2005.06.005

Zhou J, Xue K, Xie J, Deng Y, Wu L, Cheng X (2012) Microbial mediation of carbon-cycle feedbacks to climate warming. Nat Clim Chang 2:106-110. https://doi.org/10.1038/nclimate1331

\section{Submit your manuscript to a SpringerOpen ${ }^{\circ}$ journal and benefit from:}

- Convenient online submission

- Rigorous peer review

- Open access: articles freely available online

- High visibility within the field

- Retaining the copyright to your article

Submit your next manuscript at $\boldsymbol{\nabla}$ springeropen.com 